\title{
Age of Firms: Irrelevance Proposition
}

\author{
Gautam Vora \\ Anderson School of Management, University of New Mexico, Albuquerque, NM, USA \\ Email:vora@unm.edu
}

How to cite this paper: Vora, G. (2019)

Age of Firms: Irrelevance Proposition. Modern Economy, 10, 1446-1478.

https://doi.org/10.4236/me.2019.105097

Received: August 28, 2018

Accepted: May 24, 2019

Published: May 27, 2019

Copyright @ 2019 by author(s) and Scientific Research Publishing Inc. This work is licensed under the Creative Commons Attribution International License (CC BY 4.0).

http://creativecommons.org/licenses/by/4.0/

\begin{abstract}
Age of firms is used with an alarming regularity in various studies in the fields of organizational behavioral, accounting and corporate finance/law/governance, industrial economics and the like. The variable "firm age" is typically called a control variable. Why it is necessary or what it controls is infrequently explained. The variable's statistical significance or insignificance is duly noted; explanation thereof is hardly ever provided. This paper demonstrates that this variable does not provide any sensible information its users would have us believe. The paper provides numerous examples demonstrating that managerial discretion changes the nature and value of the firm, thereby negating the value of the variable. We recommend that a conceptual foundation be secured before using the variable and it not be wantonly used as a control or fixed-effect variable. Researchers would do well to report the effect size instead of merely statistical significance at some level.
\end{abstract}

\section{Keywords}

Firm Age, Control Variable, Fixed Effect, Effect Size, Irrelevance Proposition, Strategic Management, Firm Evolution, Theories of the Firm

\section{Introduction}

"Age of firm" (also "firm age"; both phrases are used interchangeably) is used with an alarming regular frequency in various studies in the fields of organizational behavioral, accounting and corporate finance, law and law and economics, corporate governance, industrial economics and the like. Rarely is the variable used as an explanatory one; the variable is typically called a control variable. Why it is necessary or what it controls is infrequently explained. The variable's statistical significance or insignificance is duly noted; explanation thereof is hardly ever provided. ${ }^{1}$

${ }^{1}$ See, for example, Kim, Park and Wier [1]. They include firm age as a variable in the empirical work "to control for the potential effect across different developmental stages of the business". 
In this paper we take on the challenge of demonstrating the irrelevance of the use of the age of firm variable. We demonstrate that this variable does not provide any sensible information its users would have us believe. Scholars who use this variable in studies in management and strategic management often appeal to Cyert and March [2] [3] $]^{2}$ or Penrose [4]. As the works of Penrose have become more popular, the use of the variable is attributed to a resource-based view of the theory of the firm. While management scholars have embraced Penrose and created an enormous amount of literature on the resource-based view and its extensions, nowhere does Penrose or her followers imply that firm age is deterrence to the production of knowledge or growth of the firm. The other two dominant views of the firm, viz., transaction-cost economics or agency theory do not make any prediction about the age and its effect on transaction or agency costs for organization. The vast literature on corporate governance is also nearly silent on the issue of firm age. ${ }^{3} \mathrm{~A}$ review of the literature across disciplines lays bare the absence of conceptual, theoretical and empirical studies using firm age as an explanatory variable (or dependent variable!) in organizational behavior studies or strategic management studies, despite its often perfunctory inclusion as a control variable. The areas of finance and accounting have seldom used the variable and typically the use is not well-integrated. The literature does offer a few instances in industrial economics where the variable is justifiably used. A majority of studies claim to use firm age as a control variable. It will not be an exaggeration to say that these studies would not lose any of their potential if the variable of firm age were left out. At the minimum one would not be able to allege that they are using it superfluously.

We first review the literature where this variable is used. We then explore a more recent debate about the interpretation of variable effect sizes which might be used to argue that age of firm variable actually does explain something meaningful. However, we find this argument to be without merit. We provide numerous examples showing that managerial discretion changes the nature of the firm, thereby negating the value of the firm age variable. We conclude that these examples demonstrate the lack of relationship between the age of a firm and its ability to adapt to environmental changes.

\section{Is Age of Firm Variable Informative?}

This section provides a review of potential theoretical bases for the use of the age of firm variable. It seems customary to attribute the relevance of age of firms to the first edition, published in 1963 [2], of Cyert and March [3]. They, however, do not address importance of the age of firms at all. Nevertheless, one may be able find an implication about age of firms from their discussion of the firm as

${ }^{2}$ Their 1963 book almost surely incorporated insights from March and Simon [5].

${ }^{3}$ Consider one of most cited survey by Shleifer and Vishny [6] to be representative of this literature. Also, visit A Survey on Corporate Governance at

https://corgovinstitute.com/a-survey-on-corporate-governance/. More discussion is provided in a section below. 
an adaptive institution ( $\$ 5.2$, pp. 117-120) and (\$5.3, pp. 120-133) because they state, "the firm learns from its experience" (p. 118) and list three basic principles of the standard operating procedures, viz., 1) avoid uncertainty, 2) maintain the rules, and 3) use simple rules (p. 121). These sections may be construed as an approximation of rigidity of the processes of decision-making or ossification of views about changing environment or status-quo mentality of the top management team, with the implication that these would increase as a firm ages and impair the ability of the firm to change itself in response to changing conditions. Even though March ([7], p. 563) is quite clear when he states, "Organizations are continually changing, routinely, easily, and responsively, but change within them cannot ordinarily be arbitrarily controlled. Organizations rarely do exactly what they are told to do." Later, on the same page, he adds:

What most reports on implementation [of public policy in public organizations] indicate, however, is not that organizations are rigid and inflexible, but that they are impressively imaginative. The ability to frustrate arbitrary intention [of an arbitrary group of public policy-makers], however, should not be confused with rigidity; nor should flexibility be confused with organizational effectiveness. Most organizational failures occur early in life when organizations are small and flexible, not later.

Despite this, researchers have continued to allude to ossification or perception thereof. ${ }^{4}$

After Cyert and March an appeal may be made to Hannan and Freeman [8] through the concept of structural inertia. In their work, however, Hannan and Freeman [8] [9] lend support to the adaptability of firms to volatile environment through the lens of ecological-evolutionary process. They examine inertial pressures on organizations, labelling this tendency "structural inertia", and scrutinize how their strength varies with age, size and complexity. The reader, however, should recognize that the claim of strong inertial pressures does not equate to the claim that organizations never change, but that organizations respond dynamically and deliberately to threats and opportunities in their environments. They state (p. 151) "structures of organizations have high inertia when the speed of reorganization is much lower than the rate at which environmental conditions change." They develop some testable propositions, viz., 1) Structural inertia increases monotonically with age, 2) Organizational death rates decrease with age (the "liability of newness hypothesis" due to Stinchcombe [10]), 3) Attempts at reorganizations increase death rates (depending on size, defined by the number of employees), 4) Complexity (of an organization which is non-hierarchical with multiple interconnected units) increases the risk of death due to reorganization. Brüderl and Schüssler [11] study West German business organizations to introduce the concept of a "liability of adolescence" and provide empirical evidence.

${ }^{4}$ Merton [13] actually anticipates March and his associates extremely well in his study of bureaucracy. He credits Mannheim [14], (revised and expanded in [15]) for the development of the concept of "rational organization". 
Hannan [12] provides three logical formalizations for empirical findings concerning the relation between organization age and the hazard of mortality. These formalizations depend on five concepts of endowment, imprinting, inertia, capability and position. Thus it is structural inertia which may hinder organizational choice in decision making, not firm age per se.

More commonly, it is the "resource-based view" (RBV) (also known as "resource-based theory" (RBT)) attributed to Penrose [4] that is often cited for the inclusion of the variable "firm age" in various empirical studies in the fields of organizational studies and strategic management where the Penrosean viewpoint of the firm as a resource-based or knowledge-based or dynamic capabilities-based entity is one of the most widely accepted perspectives. Penrose's ideas are not easily summarized. Penrose and Pitelis's ([16], pp. 11-12, Pitelis [17]) attempt, given below, is admirably clear:

1) Firms are bundles of resources, under internal direction, for use of goods and services, sold in markets for a profit. Their boundaries are defined by the area of coordination and "authoritative communication".

2) Firms differ from markets; transactions in the latter do not take place within "administrative coordination".

3) Resources render (multiple) services. The heterogeneity of services from resources gives each firm its unique character. Effective use of resources takes place when resources are combined with other resources.

4) Human, and in particular managerial, resources are of essence, because expansion requires planning and managerial resources that enable the firm to plan are firm-specific, they cannot be acquired in the market.

5) The cohesive shell of the firm helps to create knowledge. This can be "objective" (transmittable) or experience (hard to transmit). Experience renders managerial services firm-specific.

6) Unused resources always exist; they are released after the completion of an expansion and they are created through experience and new knowledge. They are an internal stimulus to growth and innovation, and determine in part the direction of expansion.

7) Firms are not defined in terms of products, but resources and (so) "diversification" is the normal state of affairs in firm expansion.

8) There are economies of growth, quite apart from any economies of size.

9) There are limits to growth, but not to size, and they are determined by the rate at which experienced managerial staff can plan and implement plans. The services of "inherited" managerial resources control the amount of new managerial resources that can be absorbed, and thus limit the rate of growth of firms.

10) The external environment is an "image" in the mind of the entrepreneur. Firms' activities are governed by their "productive opportunity", i.e., all the productive possibilities that its entrepreneurs can see and take advantage of.

11) Entrepreneurs are in search of profits; firms desire to increase total long-term profits "for the sake of the firm itself and in order to make more profit through expansion" (1959, p. 29). In the long run, growth and profits are equiv- 
alent as criteria for selecting investment programmes.

12) There exists a dynamic interaction between the external and internal environments, which creates opportunities for diversification.

13) Intra-firm specialisation leads to higher common multiples, and thus to greater specialization.

In the long run, Penrose felt that the profitability, growth and survival of firms depend on them establishing relatively impregnable bases from which to adapt and extend their operations in an uncertain, changing and competitive world. A new (productive or technological) base requires the firm to achieve a "competence" in some significantly different area of technology.

Management scholars have embraced Penrose and created an enormous amount of literature on RBV and its extensions (see, for example, Newbert [18], Acedo, Barroso and Galan [19], Rugman and Alain Verbeke [20], Wernerfelt [21] [22] Barney [23] [24] [25] [26] [27], Barney, Wright and Ketchen [28] and references therein). Often, Penrose is interpreted to mean that age of the firm produces rigidity that is unhelpful to the firm for further growth. The quest of the authors of this paper to find words to this effect in Penrose [3] has resulted in failure. ${ }^{5}$ Penrose argues that a firm's growth, both internally through organic evolution or externally through mergers and acquisitions, can be traced to the utilization of its assets. A long quote from Turvani ([37] p. 197) would help explain the limits to growth:

In Penrose's approach the firm is an administrative unit which exercises coordination and authoritative communication. It does so by bringing resources together in a certain cluster or structure, which changes over time. Intangible resources, and specially managerial and human resources [,] are put centre stage: they own the body of knowledge upon which the firm can draw.

Change is costly but also necessary if the resources available at a certain period are to be used to best advantage. In Penrose's model costs of growth are linked to the difficulties of increasing and adapting managerial resources to the changing state of affairs. In such a situation, the area of administrative coordination and authoritative communication cannot be expanded adequately with respect to the market. The reason for this must be sought in those features of growth that imply that only very rarely does a firm grow according to the logic of "more of the same". On the contrary, growth and innovation in the use of productive resources go hand in hand; innovation implies that new responsibilities and new decisions are required, often in less familiar directions. Penrose's emphasis on administrative coordination and authoritative communication as the distinctive features of

${ }^{5} \mathrm{~A}$ search in the authoritative third edition of Penrose [29] and the extensive work and commentaries of Pitelis [17] [30]-[35] and Pitelis and Pseiridis [36] has not changed the result. 
the economic organisation we describe as "firm" defines both the nature and the limitations of such a body. A firm's growth is the result of certain mechanisms that govern expansion, and foremost among these are the managerial functions. They are the basis of the coordination and communication that hold together the resources the firm has at its disposal. There is an endogenous mechanism - the active search for better ways of using internal resources-which dynamically leads to the growth of the resources the firm has at its disposal, and thus further fuels growth. Expansion, therefore, is a recurrent and unbalanced phenomenon.

The knowledge-based view of the firm considers the historical and local nature of the knowledge and the learning activities within the firm. Organizations learn and their experience is encoded in routines or operating procedures or in development of organizational capabilities. Human resources and the procedures used to mobilize human resources become crucial administrative tasks in this view. Managerial skills and cognitive models at various levels of the firm are the lens through which one gains understanding of the firm and its inner workings. Nowhere, however, do Penrose or her followers imply that firm age is deterrence to the production of knowledge or growth of the firm.

Evans [38] [39] appears to be the first researcher to explore the relationship between firm growth, firm size and firm age. His concern is growth dynamics at the micro-level. His key finding is that the probability of firm failure, firm growth and the variability of firm growth decrease as firm ages. Evans claims that the finding of the inverse growth-age relationship is consistent with Jovanovic's [40] theory of firm-learning. Jovanovic models a theory of selection with incomplete information within an industry to conclude that "Firms learn about their efficiency as they operate in the industry. The efficient grow and survive; the inefficient decline and fail." We consider the implication of relationship between age on one hand and survival and growth on the other nearly tautological. Note further that neither Evans nor Jovanovic mentions Penrose!

Leonard-Barton [41] hints that culture of the firm produces rigidity harming innovation and new product development. Incidentally note that Leonard-Barton makes no mention of age! Therefore, unless firm age is shown to cause culture that causes rigidity that causes various ills, we must remain alert to other causes of rigidities and not firm age per se. Christensen and Bower ([42], p. 199) examine hard-disk drive industry to discuss constraints imposed by large customers of the firms such that when they demand it, sufficient pressures will develop so that large, bureaucratic firms will successfully undertake technologically difficult innovations, even when these innovations require very different competences for which the firms had become well-known. ${ }^{6}$ Thus, Christensen and Bower emphasize that neither resource allocation and decision-making nor innovation-encouraging procedures or incentives, risk-consciousness and other ${ }^{6}$ Merton [13] is an early writer on bureaucracy. Stinchcombe (1965) links social structure and organizations. 
aspects of the firm's culture necessarily drive a firm to failure in the face of technological changes. ${ }^{7}$

Two other two dominant views of the firm in the business disciplines are transaction-cost economics (Commons [46], Coase [47], ${ }^{8}$ Williamson [49] [50] [51] [52]) and agency theory (Berle and Means [53], Burnham [54], Cooper [55], Alchian and Demsetz [56], Mitnick [57], Ross [58], Jensen and Meckling [59], Fama [60], Arrow [61], Levinthal [62]). Both of these theories do not make any prediction about the age of firms and its effect on transaction costs or agency costs in organizations. Thus, studies of agency and transaction costs within firms have no basis in either one of these theories to include the age of firm variable.

The vast literature on corporate governance is nearly silent on the issue. Only a few studies use firm age as a principal variable to examine an issue. Gillan, Hartzell and Starks [63] examine trade-offs among corporate governance mechanisms using a sample of more than 2300 American companies for years 1997-2000. They use age of firm as an explanatory variable measured in years since incorporation. They find that the variable is significant to explain the existence of some provisions in corporate charters. ${ }^{9}$ Loderer and Waelchli [66] explore firm age and governance of American corporations between 1976 and 2009 and come to some startling conclusions, viz., 1) as firms grow older, their performance deteriorates, 2) corporate governance quality deteriorates, and 3) corporate senescence is related to problems in retaining good employees and ideas. They use firm age as an independent (i.e., explanatory) variable, where it is defined as the number of years available in the CRSP database and named listing age. They use an additional measurement named incorporation age where age is calculated since the year of incorporation. In a similar vein, Vintilă and Gherghina [67] explore the relationship between corporate governance mechanisms and the performance of 155 American corporations for the year 2011 while using the CEO characteristics. They report mixed results. They use firm age as a control variable, where it is defined as the number of years listed on an exchange (i.e., listing age). This variable is not significant in their results. Landier, Sauvagnat, Sraer and Thesmar [68] examine American corporations between 1992 and 2009 for relation between the internal organization of the top management team of a firm and corporate performance where they use firm age as control variable. It is defined as the year when the company's data became available in Compustat and CRSP datasets. They find that firm age is negatively correlated with the dependent variable of internal governance. There is no discussion of the ${ }^{7}$ Cameron and Whetten [43] discuss organizational life cycles and organizational effectiveness whereas Henderson [44] discusses firm strategy and age-dependence. For an economist's take on this matter, see Dixit and Stiglitz [45].

${ }^{8}$ Penrose ([48], p. 1717) commented on Coase's perspective on the firm as "the two approaches are not mutually exclusive" whereas Coase (Penrose and Pitelis ([16], p. 20) commented on Penrose's perspective on the firm as "I do not regard her views as an alternative to mine..., but as a necessary addition to it."

${ }^{9}$ This is consistent with the evidence from Berry, Fields and Wilkins [64] and Boone, Field, Karpoff and Raheja [65] that board structures evolve systematically over the 10 or 11 years after a company's initial public offering. 
result.

Economists, sociologists, political scientists, and organization scientists have developed life-cycles of products and industries. The temptation to port this idea to business firms is immense. Mueller [69] develops the life-cycle of a one-product profit-maximizing firm to conclude that managers pursue a growth-maximization policy. He further draws two inferences, viz., 1) "If large mature firms are investing too much, then someone in the economy must be spending too little." and 2) "The pursuit of growth by managers [will] increase overall concentration [in the control of economic activity]." One might deduce from Mueller's phrase "mature firm" implications for the word "age" or the phrase "firm age". This in turn leads to the conjecture that firm age must be important. ${ }^{10}$ For example, DeAngelo, DeAngelo and Stulz [71], Grullon, Michaely and Swaminathan [72], Fama and French [73] use life-cycle theory of the firm to make predictions about cash flows even though the link between firm age and cash flow remains unexplained and tenuous. Loderer, Stulz and Waelchli [74], on the other hand, explore aging of the firm from a corporate management viewpoint and find support for their various hypotheses using Tobin's $q$ (estimated as the ratio of the market value of the firm's assets and the book value of these assets). Their main hypothesis is that Tobin's $q$ would fall with age, tempered by factors which increase management's attention to existing assets versus management's attention to generation of growth options. Their conjecture for this hypothesis is that the quantity of attention from top management team is limited and the age of the firm, in conjunction with competition in product market, labor market and corporate-control market, would determine the quantity allocated to the management of existing assets and the quantity devoted to developing growth options. Increased competition in product market and in labor market for managerial talent forces management to devote more attention to generating growth options whereas increased competition in the market for corporate control forces management to devote more attention to existing assets. They use numerous definitions for firm age, based on the datum availability in several standard data sources such as CRSP, Compustat, Mergent and Ritter's web site. Using the period of 1978-2009 and a sample of all listed firms in the US (except utilities and financial firms), they find support for their hypotheses. Similarly, a superb integrated use of firm age is provided by Ouimet and Zarutskie $[75]^{11}$. They posit and empirically demonstrate that 1) young firms disproportionately employ and hire young workers, 2) young employees disproportionately join young firms with potential for greater innovation and growth, and 3) a causal link exists between young workers and new firm creation.

The discussion hitherto lays bare the absence of conceptual, theoretical and

${ }^{10}$ Shumway [70] appears to be the first and unique in that he provides a justification for firm age in his conceptual framework and then empirical work and then uses the variable as an explanatory variable.

${ }^{11}$ See especially their Section 2 titled "Possible mechanisms underlying the relation between firm age and employee age" and citations therein for the conceptual foundation of their hypotheses. 
empirical studies using "firm age" as an explanatory variable (or dependent variable) in organizational behavior studies or strategic management studies. The literature throws up a few instances in industrial economics where the variable is justifiably used. The various areas of finance and accounting have seldomly used the variable and typically the use is not integrated. A majority of studies claim to use firm age as a control variable. It will not be an exaggeration to say that these studies would not lose any of their potential if the variable of firm age were left out. At the minimum one would not be able to allege that they are using it superfluously. ${ }^{12}$ In the next two sections we demonstrate that firm age is not exactly a meaningful variable regardless of the exact conceptual or numerical definition or statistical significance testing for vaguely-stated hypotheses.

\section{Statistical Inference vs. "New Statistics" of Effect Size and Confidence Interval}

The earlier section provided numerous studies from various business disciplines where the use of the variable firm age, however defined, was neither conceptually sound nor statistically meaningful. In addition the section highlighted a few studies where the use was conceptually appropriate for inclusion. In this section we discuss statistical inference as it relates to understanding of the importance of the age of firm variable. Specifically we allay doubts that there could be more importance to the variable if we examine statistics like effect size or confidence intervals in regressions using the age of firm variable.

All of the studies in the earlier section deploy traditional statistical inference methods, i.e., drawing conclusions about a population parameter from the data-set of a sample typically in the form of hypothesis testing. Traditionally business scholars have stated a null hypothesis, and once in a while, an alternative hypothesis, for a population parametric value approximated through a sample statistic. This is called the null hypothesis significance testing (NHST): The population coefficients based on general linear models are hypothesized to be zero so that statistical significance tests are simplified to an easy $t$-statistic test. The researcher calculates a $p$ value which is then used to decide whether or not to reject the null hypothesis at some significance level, most commonly $5 \%$ or $1 \%$. In other words, a hypothesis is considered statistically significant or not based on the $p$ value being less than $5 \%$ or not. Of course, alternatively the population parameter can be assumed to be non-zero, if there is enough structure to the conceptual framework. In this case, the sample provides a point estimate against

\footnotetext{
${ }^{12}$ On the other hand, one may be tempted to condone the wanton use of firm age by a misguided appeal to econometric theory that the variable could distort the results only if it is strongly correlated with independent variables and perhaps with the dependent variable, and because typically it is found statistically insignificant, the results are not biased, the interpretation is not misleading and hence the practice is harmless. Even if we were to ignore parsimony as the guiding principle of empirical work, it is precisely this type of benign neglect of solid logical foundation for researchers' conceptual model in the management literature or researchers' theoretical model in finance, accounting and economics that perpetuates the inclusion of firm age as a control variable superfluously. The inclusion does not contribute to hypotheses or their testing; it serves merely as a latent weapon against the reviews of referees and editors.
} 
which the null is tested. The procedure is almost the same. In both cases, researchers often provide confidence intervals for population parameters. Typically $95 \%$ and $90 \%$ confidence intervals are given.

One of the earliest studies to use statistical methods (Arbuthnott [76]) shows that the excess of male births is statistically significant and the excess is due to Divine Providence. NHST is actually an accidental hybrid of the tests proposed by Fisher [77] [78] and Neyman and Pearson [79]. As noted elsewhere in the literature, criticisms of NHST are quite old (Boring [80], Berkson [81]). The modern criticisms of NHST can be found in Rozeboom [82], Carver [83], Cohen [84] [85], Schmidt [86], Anderson, Burnham and Thompson [87], Thompson [88]-[93] who also provide alternatives. These criticisms have been published in numerous disciplines, such as socio-economics, education and its sub-disciplines, psychology and its sub-disciplines, ecology and wildlife science, bio-medicine, etc., and some disciplines of business such as marketing. We can only hypothesize the chagrin of these critics if they were to read the most recent article published in one of the most prestigious medical journals. Lendrem, Lendrem, Gray and Isaacs [94] study idiotic behavior. ${ }^{13}$ In their own words,

A $\chi^{2}$ test was performed comparing the observed distribution of male and female [Darwin Award] winners with the expected numbers under the null hypothesis of no sex difference... under the null hypothesis we assumed Darwin Awards were equally likely to be awarded to males and females according to their approximate distribution in the overall population (50:50).

There is a marked sex difference in Darwin Award winners. Males... made up $88.7 \%$ of... winners, and this sex difference is highly statistically significant $\left(\chi^{2}=190.30 ; \mathrm{P}<0.0001\right)$.

While a large literature exists surrounding the demerits (and a few merits) of NHST and alternatives thereof, Hubbard and Ryan [96] and Huberty [97] [98] present the history of significance testing within psychology and education. One of the best summaries of NHST problems is Kline [99] who advocates for effect sizes and confidence intervals ${ }^{14}$. A few disciplines in the social sciences have made concerted effort to move away from the traditional methods of NHST in favor of "new statistics" of effect size and confidence interval (Cumming [102]). The American Psychological Association (APA) has been a pioneer in this effort since 1994 when its fourth edition [103] of the Publication Manual advocated statistics that characterize magnitude of effect (e.g., Cohen's $d, R^{2}, \eta^{2}, \omega^{2}$ ). Effect size quantifies by how much sample results diverge from the null hypothesis. APA published the fifth edition [104] of the Publication Manual in 2001. It required the following: "For the reader to fully understand the importance of your findings, it is almost always necessary to include some index of effect size or

\footnotetext{
${ }^{13}$ We wish that they had titled their paper "Men Are Highly Significant(ly) Idiots $(p<0.0001)$ ", based on the title of the paper by Hubbard [95].

${ }^{14}$ Tyler [100] provides a "tutorial" in statistical significance. Arrow [101] discusses the choice of the level of significance for hypotheses in decision theory.
} 
strength of relationship in your results section..." (pp. 25-26). The Manual admonished "... failure to report effect sizes ..." is a "... defect in the design and reporting of research ..." (p. 5). The APA published the sixth edition [105] of the Publication Manual in 2010. It is clear about the necessity of reporting effect size:

For the reader to appreciate the magnitude or importance of a study's findings, it is almost always necessary to include some measure of effect size... Effect sizes may be expressed in the original units (e.g., the mean number of questions answered correctly; $\mathrm{kg} / \mathrm{month}$ for a regression slope) and are often most easily understood when reported in original units. It can often be valuable to report an effect size not only in original units but also in some standardized or units-free unit (e.g., as Cohen's $d$ value) or a standardized regression weights. (p. 34)

“... mention all relevant results, including those that run counter to expectation; be sure to include small effect sizes (or statistically non-significant findings)" ... (p. 32)

But for purposes of the current paper, we need not summarize the history of NHST or the criticisms of NHST or counter-arguments or alternatives. ${ }^{15}$ Cumming [102] has already provided an invaluable volume covering these topics. Cummig ([102], p. 39), Huberty [107] and Kirk [108] discuss numerous effect size measures. Rather, the concern for us is whether or not these arguments against the use of NHST have relevance in our argument against the inclusion of firm age as a variable in organizational studies. Simply, we are trying to counter-argue against a mimetic isomorphism rampant in the management literature.

In terms of the reported statistics for the firm age variable, these counter-arguments are two. 1) Whether NHST is a problem, regardless of the extent, depends on the context of the discipline. 2) Whether "new statistics" of effect size, confidence intervals and meta-analysis can shed any light on the proposition that firm age is an irrelevant variable in most of the literature of management sub-disciplines (which is not the same as business disciplines).

Ziliak and McCloskey ([109], p. 527) (ZM) in a follow-up study to the contribution of McCloskey and Ziliak [110] state that in economics

Significance testing as used has no theoretical justification. ... significance testing is getting worse. A super majority (81\%) believed that looking at the sign of a coefficient sufficed for science, ignoring size. ... The confusion between fit and importance is causing false hypotheses to be accepted and true hypotheses to be rejected. We propose a publication standard for the future: "Tell me the oomph of your coefficient; and do not confuse it with merely statistical significance."

Zellner [111] first documented the unsatisfactory use of NHST in a sample of 1978 issues of several leading economics and econometric journals and then ad${ }^{15}$ For a recent review and survey, see Mbengué ([106], especially page 119) with its incendiary title. 
vocated Bayesian analytic methods for significance testing. ${ }^{16} \mathrm{~A}$ few leading econometricians respond to the claim of Ziliak and McCloskey. Elliott and Granger [114] point out the fundamental lacuna in ZM's argument that they never discuss the question of the purpose of an economist's model; the quality of the whole model matters more than the NHST on variables. Horowitz [115] points out that 1) random sampling errors are not unimportant, 2) often the existence of a phenomenon, not its size, is important, and 3) NHST is unavoidable for detecting specification errors in econometric models. Leamer [116] dismisses ZM's claim altogether. O'Brien [117] concentrates of the definition and quantification of oomph and argues that the poor use of NHST would sink very few economics papers because statistical significance is not central to their empirical efforts. Wooldridge ([118], p. 578) provides vivid counter-arguments:

... pushing an economically large effect that is statistically insignificant is usually a stretch. Suppose I sample 10 high-school graduates from a population, and estimate a return to each year of college of $30 \%$, but with a $t$ statistic of one. Should I then make policy based on the $30 \%$ figure? If another researcher uses 5000 observations and estimates the return to be $12 \%$ with $t=$ 20 , should I prefer the $30 \%$ estimate because it is economically more important?

I see a growing problem of instances where researchers ignore statistical significance, and statistical issues more generally, and focus too much on magnitude in order to push a particular story or policy. As an example, it has become a cottage industry in empirical microeconomics to find a clever instrumental variable for an endogenous explanatory variable. Naturally, ordinary least squares estimation is set up as the straw man, and then instrumental variables estimation (usually two stage least squares) is used to solve the endogeneity problem. Often-especially if the paper is published in a good journal-the 2SLS estimate is bigger in magnitude than the OLS estimate. Even in cases where a Hausman test fails to reject that OLS is consistent, researchers often appeal to the 2SLS estimate for policy discussions.

Wooldridge observes that as more nonlinear models (leading examples being probit, logit and Tobit) are used, more researchers use a discussion of the signs of the coefficients when the their estimates are not meaningful.

Gigerenzer ([119], p. 588) provides a description of three-step hybrid procedure (step 3 is interesting) for NHST used mostly by psychologists and contrasts it from the three-step procedure proposed by Fisher (p. 590) and the three-step procedure proposed by Neyman-Pearson ([79], pp. 590-591). The following paragraph from Gigerenzer (pp. 591-592) ${ }^{17}$ is priceless:

Fisher is the best known of the inadvertent "fathers" of the null [NHST] ritual. His influence has divided psychologists deeply, and interestingly, the

${ }^{16}$ See also Lecoutre [112] and Lecoutre, Lecoutre and Poitevineau [113] for advocacy of Bayesian methods.

${ }^{17}$ See Gigerenzer [119] for references in the paragraph. 
rift runs between the great personalities in psychology on the one hand, and a mass of anonymous researchers on the other. You would not have caught Jean Piaget calculating a $t$-test. The seminal contributions by Frederick Bartlett, Wolfgang Köhler, and the Noble laureate I.P. Pavlov did not rely on $p$-values. Stanley S. Stevens, a founder of modern psychophysics, together with Edwin Boring, known as the "dean" of the history of psychology, blamed Fisher for a "meaningless ordeal of pedantic computations" (Stevens, 1960, p. 276). The clinical psychologist Paul Meehl (1978, p. 817) called routine null hypothesis testing "one of the worst things that ever happened in the history of psychology," and the behaviorist B.F. Skinner blamed Fisher and his followers for having "taught statistics in lieu of scientific method" (Skinner, 1972, p. 319). The mathematical psychologist R. Duncan Luce (1988, p. 582) called null hypothesis testing a "wrongheaded view about what constituted scientific progress" and the Nobel laureate Herbert A. Simon (1992, p. 159) simply stated that for his research, the "familiar tests of statistical significance are inappropriate."

For the endemic problems and pitfalls of NHST and poor statistical reporting practices in scholarly research both Gigerenzer ([119], pp. 592-294) and Altman [120] blame the culture of publishing and journal editors.

While the substantive differences in conceptual framework, theoretic modeling and empirical methods have diminished the ardor for new statistics in economics and finance, the similarity of framework, instruments and methods has brought the crusade of new statistics of effect sizes and confidence intervals over into business (functional) disciplines such as marketing (Sawyer and Peter [121]) and (support) disciplines such as forecasting, ${ }^{18}$ human resources (HR) and international business (IB) management.

Since the seminal articles by Huselid [124] and MacDuffie [125] on the impact of HR practices on firm performance, a large number of papers has examined various aspects of these practices. Methodological issues are examined by numerous papers beginning with Huselid [126] and continuing with Gerhart [127], Gerhart, Wright, McMahan and Snell [128], Gerhard, Wright and McMahan [129], Huselid and Becker [130] and Wright et al. [131]. Combs, Liu, Hall and Ketchen [132] provide a meta-analysis of high-performance work practices and organizational performance using effect size. ${ }^{19}$ Becker and Huselid [133] explore ${ }^{18}$ See Armstrong ([122] [123]).

${ }^{19} \mathrm{~A}$ footnote in Table 2 (p. 514) and Table 3 (p. 516) states "If $\chi^{2}$ is significant, we assume residual variance is heterogeneous. Otherwise, homogeneity is assumed." In the text (p. 513) the authors explain, "When $\chi_{K-1}^{2}$ was not significant, the effect was considered homogeneous (i.e., one population effect with no remaining moderators). All variance is assumed to be due to sampling error, and the standard error of sampling error variance was used to create confidence intervals for the homogeneous case. When significant variance remained unexplained, a wider confidence interval was used based on the standard error of the total effect size variance." It is hard for an uninitiated reader to appreciate whether $\chi_{K-1}^{2}$ is Cochran's $\mathrm{Q}$ and whether the individual studies meet the criteria for combinability. We will not go into the issues of field studies and their conceptual foundations in terms of alternative explanations, omitted variables, measurement errors, simultaneity and structural causation. 
the conceptual and methodological issues for strategic HR management for field study as well as meta-analysis.

In the domain of international business (IB), Ellis [134] provides an excellent survey and meta-analysis. He aggregates 965 individual study-specific estimates drawn from meta-analytic studies published in 32 IB journals and surveys 204 studies published in the leading IB journals. He finds that the average effect size in this literature is small and most published studies lack the statistical power to detect effects reliably. He concludes that researchers are under-selling their results by emphasizing $p$ values instead of effect size estimates. Given Ellis's [135] [136] discussion of thresholds for interpreting effect sizes, he concludes that inattention to statistical power can lead to both Type I and Type II errors. He laments ([134], p. 1585) that "international business researchers neither report nor interpret their estimates of effect size" and found only one noteworthy exception.

The foregoing paragraphs have taken care of three issues: 1) This article is not about the pros and cons of NHST. A good literature exists about that. 2) This article is not about the new statistics of effect size, confidence interval and meta-analysis. A good literature exists about that. The new statistics is more used in the literature on psychology, education, medicine, ecology and the like. The use of new statistics is sparse and poor in HR and IB literature. 3) The "new statistics" of effect size, confidence intervals and meta-analysis cannot shed any light on the proposition that firm age is an irrelevant variable because HR and IB literature where new statistics has been used sparingly does not use the variable.

An additional issue needs to be discussed in the context of research methods: The tendency to throw in as many variables as possible in an empirical equation, typically a general linear model, lest the researcher be accused of the sin of omitted variables! This "kitchen sink" approach does not enhance the research design at all. Like many other variables, firm age is often included either as an explanatory variable or as a control variable without much discussion about its role and expected effect, never mind the effect size.

The next section gives a few detailed examples to support our proposition. In the spirit of Simon ([137], p. 159), weaver that for our proposition the familiar tests of statistical significance are as inappropriate as meta-analysis. The proof of our proposition flows from logic and axioms rather than statistics.

\section{Illustrations}

With a select few examples, we highlight the incontrovertible fact that firm age is unlikely to capture much information because many things in both internal and external environments change dramatically over time. These changes affect the mature firms as much as the young ones. The internal changes may not necessarily be in response to external changes.

The internal changes are typically transformative so much so that the inherent character of the company changes. These changes are often accompanied by 
changes in the top management team and board of directors as well as in total number of employees worldwide. Almost all companies, not only the companies highlighted below, are constantly undertaking restructuring with regards to acquiring and selling divisions or lines of businesses, with such moves often involving layoffs. Their plans-strategic and short-term-are in a constant flux; in the business jargon, they are described as "opportunistic". The emphasis on core competence is often replaced by the desire to acquire a new profitable opportunity either from outside or through its own R\&D efforts. Even if the core business remains the same, the developments in supply chain and delivery of goods and services to customers cause commensurate changes internally. Changes in the top management team results in changes in the strategic direction of the company.

The external changes have many progenitors. Changing tastes and preferences of consumers is one of the most obvious ones. Economic cycles and financial environment, legal and regulatory climates, tax policies of home country and foreign countries, labor relations, domestic politics, geo-political cross-currents and the like have major influences on the plans and operations of a company.

Add to the above the winds buffeting a multinational corporation (MNC). Today's MNCs have physical operations in many countries. These MNCs are subjected to pressures from all these countries and their relationships with other countries. Perturbations overseas have consequences for the operations and profitability of MNCs. In addition, these companies operate under constraints imposed by some supra-national bodies such as the World Trade Organization (WTO) (formerly General Agreement on Trade and Tariffs (GATT)), Bank for International Settlements (BIS), International Monetary Fund (IMF) and International Bank for Reconstruction and Development (IBRD, more popularly known as the World Bank), etc.

The clear-cut implication of the foregoing is that the age of the firm becomes less informative as an explanatory variable for the behavior of the firm and redundant as a control variable. Given this conclusion we posit that the best way to conceptualize a firm is to consider it a dynamic system (contrasting from a static system) which evolves in response to internal and external stimuli. The factors influencing a firm's behavior are different at different periods of time and there is unlikely to be a single dominant factor constant through the firm's evolution.

The following examples will demonstrate this thesis emphatically.

\subsection{Nokia}

Today Nokia is known as a Finnish communications and information technology company with headquarters in Espoo, Uusimaa, Finland..$^{20}$ The company provides Internet services as well as applications, games, music, media and messaging services, etc., and telecommunications network equipment and services. In

${ }^{20}$ See http://company.nokia.com/en/about-us/our-company/our-story and http://en.wikipedia.org/wiki/Nokia. 
September 2013 the company sold what was once the world's largest maker and seller of mobile phones (to Microsoft) for about $\$ 7$ billion. As of 2013, the company employed about 90,000 persons and had presence in over 150 countries. The company is listed on the Helsinki Stock Exchange and New York Stock Exchange. Its revenues in 2013 put the company at 274th largest company in the Fortune Global 500 list.

Nokia started in 1865 with a wood pulp mill at the Tammerkoski rapids in Southwestern Finland. The name was changed to Nokia Ab in 1871 when the company opened a second pulp and paper mill on the banks of the Nokianvirta river. For over 30 years, the company was run successfully as a conglomerate with disparate lines of business. In 1902 the company added electricity generation as an additional line of business. In 1967 the name was changed to Nokia Corporation when the company merged with Finnish Rubber Works, a manufacturer of rubber boots, tires and other rubber products and with Finnish Cable Works Ltd., a manufacturer of telephone and power cables. This company had five lines of business, viz., rubber, cable, forestry, electronics and power generation. Its product line was wide, producing "paper products, car and bicycle tires, footwear, communications cables, televisions and other consumer electronics, personal computers, electricity generation machinery, robotics, capacitors, military communications and equipment, plastics, aluminium and chemicals". ${ }^{21}$ The company exited consumer electronics business in the 1990s. The manufacture of tires was spun off in 1988 and that of footwear in 1990. The original paper business was sold in 1989. During the decade the company divested itself of all other non-telecommunications businesses. By 1998 its focus on telecommunications and its early investment in a particular mobile phone technology made the company the world's largest mobile phone manufacturer, a position it held until 2012.

In 2013 Nokia underwent two "transformative transactions". It acquired Siemens' 50 percent ownership in their joint-venture Nokia Siemens Networks and sold its Devices \& Services business to Microsoft. These transactions left Nokia with three businesses, Nokia Networks, HERE, and Nokia Technologies. The first is the telecommunications equipment and services, the second is the mapping services and the third is developing and licensing of its internally-developed advanced technologies. Post-transformation, Nokia broke with the tradition to hire a non-Finn to be the CEO.

Can we consider Nokia as a static firm $?^{22}$ No. Would we expect firm age to ${ }^{21}$ See http://en.wikipedia.org/wiki/Nokia.

${ }^{22} \mathrm{~A}$ static firm can be defined by contrast with a dynamic firm. A dynamic firm is trying to sustain its competitive advantage by constantly adapting to changing circumstances in various markets in which it participates. This adaptation would help the firm to be a continuing firm, yet the adaptation would change the inherent nature of the firm, including its business model. If a firm wishes to be a long-lived firm, then it must continually evolve; it cannot remain the same. Even the fundamental accounting principle of "going concern" inform us that a company will be able to continue operating for a period of time that is sufficient to carry out its objectives, obligations, promises without jeopardizing the invested capital and this is possible only if the company adapts. 
provide any explanatory power with respect to asset rigidity, managerial discretion, etc.? No.

\subsection{CBS}

CBS Corporation is one of the most interesting evolutions of a company. Additionally we will need to distinguish between CBS as a brand and CBS as a company, recognizing the phenomenon of brand names as assets that can be licensed or sold. Additionally this example can be labelled as "CBS/Westinghouse/Viacom" because of the complex history, even though we will retain the focus on CBS.

Today's CBS Corp. is a well-known commercial broadcast television network which also owns radio network, numerous TV-and radio-stations in large- and mid-size markets, publishing groups and some cable networks. The name reflects a convoluted history.

The company was incorporated in 1927 as United Independent Broadcasters, Inc. The name was changed to Columbia Broadcasting System in 1928 by William S. Paley as the president who later in the same year became the majority owner. In 1974 the company changed the name to CBS Inc. In 1995 the Westinghouse Electric Corp. acquired CBS Inc. and in 1997 changed its own name to CBS Corp. (Note that Westinghouse Electric Corp. itself was founded in January 1886 as Westinghouse Electric Co. and later renamed by the founder George Westinghouse himself. The company was engaged in long-distance high-voltage AC power transmission. Later it designed and developed nuclear reactors for the US military's submarine and aircraft carrier. ${ }^{23}$ )

CBS continued to prosper as a radio network concentrating on music, comedy and variety shows, a large number of which were directed at women. In 1934 it launched, much to the consternation of newspapers and wire services, its independent news division hiring a year later Edward R. Murrow. Murrow and Murrow's Boys (William L. Shirer, Charles Collingwood and Eric Sevareid) developed the News Round-Up format which is the mainstay of radio and TV news today. The decade of 1950s saw CBS struggle against the RCA-system of color TV preferred by both $\mathrm{NBC}$ and $\mathrm{ABC}$ as well as the rivalry between its preferred UHF frequency band versus more capacious VHF band. TV proved to be a disruptive invention such that most of the successful programs moved from the radio medium to the TV medium; unsurprisingly, money and profits followed suit. During these years, CBS continued with buying and selling radio stations and TV stations throughout the country. The decade of 1970s saw CBS do better than other networks in terms of programming and profits.

While the businesses of radio and TV broadcasting were moving up, the management of the company was undergoing substantial changes. Earlier CBS's

\footnotetext{
${ }^{23}$ Westinghouse's own interesting history can be provided as another illuminating illustration of companies undergoing unbelievable changes. The company itself is now defunct. The successors to the company are Westinghouse Licensing Corp. (1998) and Viacom (1999). In 1999 CBS Corp. sold its nuclear business as Westinghouse Electric Co. to British Nuclear Fuels Limited (BNFL) which in turn sold it in 2005-2006 to Toshiba which still runs the company as nuclear power plan designer, developer and operator.
} 
acquisitions were in the mainstream of broadcasting business. CBS, entering the 1960s, wanted to diversify. In 1965 it acquired Fender electric guitars and Rhodes electric pianos. These efforts were not exactly successful. In other equally less-successful efforts the company would buy (and later sell) sports teams (e.g., New York Yankees), publishers (e.g., Fawcett Publications, Holt, Rinehart and Winston, Saunders, Bond/Parkhurst, Ziff Davis, etc.), map makers, toy manufacturers (e.g., Gabriel Toys, Child Guidance, Wonder Products, Gym Dandy, Ideal, etc.), home video recording system, etc. In 1964 its Gulbransen Organs, a division making various home organs was merged with Seeburg Corporation and production was ceased in 1969 until 1985 when Mission Bay Investments acquired the brand.

In the decade of 1980s, the company itself was put in play by Ted Turner and was saved by Laurence Tisch of Loew's Inc. who later acquired the control of the company. The company sold off Columbia Records to Sony in 1988, in 1985 sold a part of book publishing to Harcourt Brace Jovanovich and another part to Holtzbrinck, sold the magazine business in 1987 to its then-executive Peter G. Diamandis who later sold in 1988 the assets to Hachette Filipacchi Media at a profit of $\$ 303$ million. CBS closed CBS Technology Center (an original R\&D lab) and other businesses, including Fender, and Rogers Drums in 1983. Also during this time a new company was formed. This was Steinway Musical Properties brought together from CBS Rodgers Organs, Gemeinhardt flutes and Steinway Pianos. Other musical instrument properties were liquidated.

In 1982 the company made another attempt, after abandoning its production unit in 1972, at film production in a joint venture, TriStar Pictures, with Columbia Pictures and HBO. The stake was sold in 1985 to Coca-Cola Company, the then-owner of Columbia Pictures. The company's romance with home video market started in 1978 in a joint venture with MGM and ended in 1982.

By mid-1990s, majority stakeholder Tisch was becoming less satisfied at the trajectory of profits. The company was sold outright to Westinghouse in 1995 for $\$ 5.4$ billion. Westinghouse acquired and traded numerous radio stations, TV stations and cable channels. In 1997, Westinghouse changed its name to CBS Corp. while the headquarters was moved from Pittsburgh to New York. The new company put up all non-entertainment assets for sale. By the end of 1999, all pre-CBS elements of the industrial past of Westinghouse had disappeared.

By the end of the year 1999, however, a new suitor emerged. A division started by the original CBS in 1952 and spun off as Viacom in 1971 that had become a giant communication and media conglomerate under the majority ownership of Sumner Redstone announced a takeover of CBS for $\$ 37$ billion. The takeover was completed in 2000 .

By 2005, however, having found that the communication and media empire he had assembled was not performing at the level he had hoped, Redstone split Viacom into two under the umbrella of his holding company National Amusement. One part became CBS Corp. keeping the earlier CBS, Paramount Television's production operations, United Paramount Network (UPN), Viacom 
Outdoor advertising, Showtime Network, Simon \& Schuster publishing house (later sold), and Paramount Parks (later sold). The other part retained the name Viacom and kept the portfolio of assets such as MTV Network, Black Entertainment Television (BET) and some music and recording studios. Since this "reorganization", CBS has undertaken many other acquisitions to become the owner of one of the largest libraries of film and TV programs.

Can we consider CBS/Westinghouse/Viacom a static company? No. In addition, recognize the elements and pace of change because of extremely strongly-held views and management practices of the majority stakeholders such as Paley, Tisch and Redstone, showing considerable managerial discretion unrelated to firm age.

\subsection{International Business Machines (IBM)}

Today IBM is known as one of the largest, multinational computer technology, information technology (IT) and IT consulting companies in the world. It has a continuous history since $1880 \mathrm{~s}^{24}$ The forerunner is the Computing-Tabulating-Recording Company (CTR) incorporated in 1911 by the businessman and financier Charles Ranlett Flint. The incorporation was undertaken to meld the businesses of the various independently functioning companies among which the most prominent were Computing Scale Company of America (a maker of mechanical scale which calculated the weight of the item on the weighing platform, incorporated in 1891), the Tabulating Machine Co. (a maker of punched card tabulating equipment, incorporated in 1896 by Herman Hollerith), the International Time Recording Co. (a holding company for the Bundy Manufacturing Co., the Standard Time Stamp Co. and the Willard and Frick Manufacturing Co., organized in 1900) and the Bundy Manufacturing Co. (a maker of time-recording equipment, incorporated in 1889), and others such as Dey Time Register Co., Stimson Computing Scale Co. and Moneyweight Scale Co. CTR was established as a holding company whose board sought an executive not previously affiliated with any of the portfolio companies to integrate them into one harmonious business. The board hired Thomas J. Watson, Sr., on May 4, 1914 as general manager. ${ }^{25}$ In February 1924, the name was changed to International Business Machines Corp., a name which had been registered in New York since 1918 and first used in 1917 when International Business Machines Co. Ltd., was established in Canada. Therefore, IBM recognizes 1911 as the establishment year and celebrated its centennial in 2011.

Since 1911 IBM has undergone many changes of personnel and businesses and employees. Today the company has scientists, engineers, consultants, as well as marketing and sales professionals in over 170 countries. Impressively IBM employees have received five Nobel Prizes, ${ }^{26}$ six Turing Awards, ${ }^{27}$ nine National

\footnotetext{
${ }^{24}$ See IBM FAQ at http://www-03.ibm.com/ibm/history/.

${ }^{25} \mathrm{IBM}$ has in the past traditionally recognized this date as its anniversary.

${ }^{26}$ See http://ibmresearchnews.blogspot.com/2013/05/ibm-research-zurich-officially-turns-50.html.

${ }^{27}$ See section A.M. Turing Award Recipients at

http://researcher.watson.ibm.com/researcher/view_group.php?id=1758.
} 
Medals of Technology and Innovation (not counting the two corporate awards) ${ }^{28}$ and five National Medals of Science ${ }^{29}$ among many accolades ${ }^{30}$. The history of IBM's evolution is exceedingly well presented by IBM itself and others. ${ }^{31,32}$

Our interest in this history starts from 1980s-1990s. These decades are marked by the twin computer tech revolutions, viz., the PC revolution that put computers directly on the desks of the users and the distributed network revolution that linked clients (the users and their machines) with servers (the larger computers that served as the hubs of data and applications) thereby breaking the prevailing dominant business model of mainframes and super-minis with their tethered dumb (and some smart) terminals. The purchasing decisions went from a concentrated location in enterprises to departments and individuals. The importance of "integrated solutions" was diminished. By 1993 the company's annual net losses had reached $\$ 8$ billion. IBM was considering drastic changes to its businesses and organizational structure.

In April 1993, however, IBM hired Louis V. Gerstner, an outsider, as its new CEO after forcing out Chairman and CEO John Akers. Declaring that “... last thing IBM needs right now is a vision", Gerstner focused on execution, decisiveness and integration of business units for providing integrated service to customers. Instead of splitting up the company, he worked on these steps which stabilized the company to bring back profitability. He managed to sell off the Federal Systems Division to raise cash and began a cost-cutting program. During the refocusing, Gerstner shrank the employee headcount from about 375,000 in 1990 to about 225,000 in 1995 . Over the next decade, he overhauled the company by shedding "commodity" businesses such as DRAM memory, networking, personal printers, hard drives, some pieces of software, etc. He turned the company into an IT service provider with loss-leader or barely-profitable hardware followed by services as an add-on. By the end of 1994, IBM stopped development work on OS/2, the competing operating system for PCs. It withdrew from the retail desktop PC market altogether and ultimately sold the PC and laptop division to Lenovo in 2005. IBM became a services-oriented company from a manufacturing company; it augmented the services business in 2002 by buying the consultancy division of PriceWaterhouseCoopers for $\$ 3.5$ billion. IBM hardware and $\mathrm{R} \& \mathrm{D}$ were deployed to upgrade its existing product lines. As the Internet,

\footnotetext{
${ }^{28}$ See section National Medal of Technology at

http://researcher.watson.ibm.com/researcher/view_group.php?id=1758.

${ }^{29}$ See section National Medal of Science at

http://researcher.watson.ibm.com/researcher/view_group.php?id=1758.

${ }^{30}$ For example, the Wolf Foundation Prize for physics for 1993 was awarded to Benoit Mandelbrot for his paper "How Long is the Coast of Britain? Statistical Self-Similarity and Fractional Dimension”, Science (1967).

${ }^{31}$ See http://www-03.ibm.com/ibm/history/history/history_intro.html. Also, see http://en.wikipedia.org/wiki/IBM and http://en.wikipedia.org/wiki/History_of_IBM.

${ }^{32}$ Note that IBM's web site is silent or skimpy on anti-trust suit and documents thereof for which one can turn to an excellent curated depository, Richard Thomas deLamarter Collection of IBM Antitrust Suit Records, maintained by Hagley Museum and Library, at http://findingaids.hagley.org/xtf/view?docId=ead/1980.xml.
} 
networking and web-based applications became the new paradigm for its customers, IBM was ready for another tech revolution as it could supply the middleware and services without demanding that the customer buy IBM hardware. On the hardware side and R\&D side, IBM became one of the largest players in custom chip design and manufacture for different applications and devices and became a leader in developing super-computers. Gerstner retired in 2002. While he saved the company, he could not stave off its decline as IBM lost its once-dominant position in the industry which it had defined and created. In addition to the IT businesses, IBM has become one of the largest holders of intellectual property in the form of patents. It has the highest number of U.S. patents among all of corporate America. For example, from 1993 through 2007, it was awarded over 38,000 patents which may be considered ample reward for investing about $\$ 5$ billion per year in R\&D since 1996. Currently the company is trying to compete in cloud computing and data storage with the likes of Amazon and Google.

Can we consider IBM a static company? No. In addition recognize the elements and pace of change because of rapidly fluctuating external environment which resonated with a new $\mathrm{CEO}$ who found the wherewithal to respond meaningfully and successfully. Again, IBM's history shows a lack of relationship between asset rigidity, managerial discretion, and firm age.

\subsection{General Electric Co. (GE)}

Though General Electric has gone through many transformations which we argue render firm age a meaningless measure with regard to the company, a more recent example drives this point home. On Sept. 8, 2014, GE, which commercialized the electric toaster and self-cleaning oven, announced that it would sell its appliance business to Sweden-based Electrolux AB for $\$ 3.3$ billion. Electrolux will continue with GE brand-name. The sale will leave one of the original conglomerates in only a few business lines, namely, non-consumer finance and industrial equipment such as power-generation turbines, aircraft engines and medical devices like CT scanners. The shift is attributed to Jeffrey R. Immelt who in his 14th year as CEO was adjusting to competitive pressures and trying to boost a long-sluggish stock price. Under Immelt GE has sold off businesses as diverse as insurance, plastics, media, consumer finance and now appliances. And, under Immelt GE has spent around $\$ 14$ billion acquiring oil-and-gas service companies. In 2013 energy and energy-related activities contributed about one-third of the company's revenues and more than 40 percent of its operating profit. Its non-bank finance division, GE Capital, contributed about one-third of the company's revenues and around 50 percent of its operating profit.

Can we consider GE a static company? No. The ascension of Immelt after the long-tenure of John F. "Jack" Welch (became Vice Chairman in 1979, Chairman and CEO in 1981, resigned in 2001) heralded the New GE Way of innovation and transformation (Magee [138], Owles [139]). Immelt's moves again unders- 
core the lack of a relationship between asset rigidity, managerial discretion, and firm age. While Immelt became celebrated in political circles and in Corporate America, the firm suffered because of his missteps and he stepped down in 2017, after being at the helm for almost 16 years. The board of directors and top management team underwent a major restructuring along with the firm itself while the value destruction reached $\$ 100$ billion. Immelt was succeeded by John Flannery, head of GE's health-care division. On 1 October, 2018, he was unanimously voted out by the board after announcing a $\$ 23$ billion loss on its power business division. Flannery was replaced by H. Lawrence Culp, a former chief executive of Danaher Corp. These changes of leadership reflect a growing recognition that the firm may not survive in its current form. The rating of the bonds of GE has been reduced in the last several years. All-told GE's equity value has lost about half-a-trillion dollars since Welch retired in 2001. Financial press has started mentioning that Welch failed in succession planning and grooming successors to manage a complex conglomerate (Bennett [140], Colvin [141], Gryta and Mann [142]).

\subsection{Unilever (London and Rotterdam)}

The Anglo-Dutch firm, Unilver, is one of the most well-known international firms. It is a dual-listed firm comprising of Unilever PLC (London) and Unilever N.V. (Rotterdam) with two headquarters at London and Rotterdam. Its products span the space of food and beverages, cleaning items and personal care. Unilever's history since 1871 is a history of changes, expansion, and innovations. The web site of the firm at https://www.unilever.com/about/who-we-are/our-history/\#timeline+2D+none+ closed provides a detailed history of its existence in one form or another since 1860. The firm gained its current form in 1929 after the merger of the businesses of Dutch Margarine Unie and British soap-maker Lever Brothers. The Wikipedia page on the firm at https://en.wikipedia.org/wiki/Unilever gives a nice summary of the changes in business lines and divisions through mergers and acquisitions and spin-offs.

Unilever is considered so attractive that a much-smaller firm, Kraft Heinz, made a $\$ 143$ billion unsolicited bid to acquire it. The bid was rejected and Unilever remains independent continuing its businesses across the world. As the history of Unilever makes clear the firm has hardly stayed the same though the years; it has constantly been changing. Currently it has organized itself in four multi-country divisions, viz., 1) Personal Care, 2) Foods, 3) Refreshments, and 4) Home Care. Unilever's main international rivals are Nestlé and Procter \& Gamble. We devote the next subsection to a brief history of Nestlé.

\subsection{Nestlé}

Nestlé is an international Swiss firm, founded in 1905 by the merger of Anglo-Swiss Milk Co. (established in 1866) and Farine Lactée Henri Nestlé (established in 1866). The firm grew rapidly throughout the years, but the significant 
growth came during the world-war years. It has become the largest food company in the world. The web site of the firm at

https://www.nestle.com/aboutus/history/nestle-company-history provides a detailed history of its existence. The Wikipedia page on the firm at https://en.wikipedia.org/wiki/Nestl\%C3\%A9 gives a good summary of the firm's life. The major business lines of the firm are 1) powdered and liquid beverages, 2 ) milk products and ice cream, 3) prepared food dishes and cooking agents, 4) nutrition and health-related products, 5) pet-related products, 6) confections, and 7) bottled water. Many of these business lines were acquired and expanded as well as developed in its R\&D labs. In many countries, Nestlé has run into numerous food-related controversies and legal suits on safety of its products. As Nestle's web site reveals, the firm has constantly adapted to the market place. Because it operates in most of the countries in the world, it, its products, and its management-corporate and local-are constantly evolving in the face of pressures in each country and market. As the evolution occurs, the firm changes in its essence.

\section{Further Thoughts}

We can pick almost any medium or large company, publicly- or privately-held, based in the U.S. or elsewhere. ${ }^{33}$ For foreign companies we could have picked other well-known examples of 1) Bayer AG whose nature has been changing as it has acquired firms in animal health, crop science and pharmaceuticals. Bayer has not been to digest the products lines bought from Merck and has been saddled with large legal problems related to products of Monsanto; or 2) Fiat Chrysler Automobiles whose nature has been changing as operations of two brands are still not on an even keel; or 3) Renault-Nissan-Mitsubishi Alliance whose nature has been changing because of brands, markets, marketing and promotion, and inter-country rivalries. For US companies we could have picked other well-known examples of a) United Technologies Corp. whose nature has been changing as it acquired and is now trying to spin itself off into three companies; or b) Amazon.com, Inc. whose nature has been changing as it began its life as a book-seller and has now become a major force in e-commerce, music and video streaming, cloud computing, and many other lines of business; or c) Land O'Lakes, Inc., a co-operative established in 1921, with more than 1700 farmers as current owners, that started in butter business and expanded into many different lines of business and business models.

If we dissect a firm's history properly we will see that change is constant. The company has changed its essential character in response to various internal and external factors. Even the most mature companies such as Procter \& Gamble, Coca-Cola, and PepsiCo as well as specialized companies such as Steinway Pianos, DuPont, and Kodak go through dramatic changes. ${ }^{34}$ This phenomenon is

\footnotetext{
${ }^{33}$ We reluctantly refrain from providing more illustrations because of limitation of space.

${ }^{34} \mathrm{We}$ are not sure how one can discuss a firm such as AT\&T because it represents an extreme case of changes through its history.
} 
not restricted to US companies. Almost all firms, regardless of domicile, undergo changes. ${ }^{35}$ To ascribe any particular behavioral traits to firms because of their age is not sensible.

\section{Conclusions}

This paper argues against the unjustified use of the variable "firm age" in business disciplines, especially in management studies. A theoretic justification for the variable must be provided either as an explanatory variable or as a control variable. The casual, perfunctory use of the variable in empirical studies is decried because it diminishes the value and insights of the studies. Illuminating illustrations are provided to highlight changes in the essential nature of a company.

This importance of the irrelevance proposition is grounded in the importance of theoretical and empirical parsimony. The use of firm age as a control variable is ubiquitous in the management literature. We question its inclusion first on theoretical grounds by showing that the authors cited to support the use of firm age actually offer no such support. But, we also question its inclusion based on the proxies that are used to measure this variable. Simply, the idea that the number of years a firm has been in existence or listed on a major stock should explain anything related to rigidity in and constraints upon managerial decision making is hard to support given the rampant restructuring undertaken by large firms. We suggest that the statistical non-significance often seen for firm age is related to its measurement. The variable, as measured, does not actually capture what the authors argue is theoretically important, that being a measure of managerial and asset rigidity.

The irrelevance proposition is innovative in the way that anyone willing to say "The emperor has no clothes" is innovative. We are challenging conventional wisdom in this article. It is also innovative in this age of ever-more powerful computers which allow for the easy inclusion of explanatory variables without actually thinking about the parsimony of the models being tested. In our discussion, we surface and challenge the strongly held beliefs about the importance of the firm age variable, including the citations to the authors who supposedly argue for its importance, such as Penrose.

We hope that the scholars who study empirically issues in strategic management, management, corporate governance, theory of the firm, finance, accounting and entrepreneurship heed our advice. Some of these groups may not be regular readers of some of these journals but they are likely to use the same journals as a major source in literature searches for cross-disciplinary research. Scholars in traditional business disciplines such as finance, management or accounting, provide some justification for the use of the variable firm age, but our sense of its use is that of mimetic isomorphism rather than a theory-driven ne-

${ }^{35}$ For example, the history of Shell says more about the owners, managers and their vision than about the age of the company. 
cessity for its inclusion. Indeed, scholars in empirical research in various branches of management routinely use the said variable without providing much justification for the use of the variable. This paper is intended to speak to any researchers who include a measure of firm age simply because they learned in graduate school that one needed to include the years that a firm has been in existence or listed on a stock exchange because it has some mystical importance related to firm rigidity. Thus our real purpose is to have researchers ask a basic question: Why do we include firm age as a variable when our measure for it probably has little relationship to the theoretical idea we are trying to capture?

The scholarly writers of management, strategic management, and organizational behavior should ideally stop using the variable firm age unless they can provide a conceptual or theoretical foundation for it. Their use of the variable is all too often predicated on flimsy grounds that this researcher or that researcher has used the variable as a control variable. The clear-cut implication of the foregoing is that the age of the firm becomes less informative as an explanatory variable for the behavior of the firm and redundant as a control variable. Given this conclusion we posit that the best way to conceptualize a firm is to consider it a dynamic system (contrasting from a static system) which evolves in response to internal and external stimuli. The factors influencing a firm's behavior are different at different periods of time and there is unlikely to be a single dominant factor constant through the firm's evolution. The casual, perfunctory use of the variable in empirical studies is decried because it diminishes the value and insights of the studies. If parsimony is as valued as researchers suggest, the inclusion of the firm age variable, as measured, is a distraction from the theoretical and empirical insights that researchers are offering. As demonstrated earlier, no firm is able to continue to exist on a single, historically-established form. If the firm does not adapt, it will perish. Even the leadership changes bring about changes in the behavior of the firm.

The future direction of research in this area is easy to point, and yet difficult to travel. A promising start would be for each discipline to undertake a meta-analysis. A meta-analysis would serve at expounding on at least two functions: 1) Statistical tests of significance and effect size and 2) Nature and role of the variable. Such research would provide a conceptual foundation for further research.

\section{Acknowledgements}

I thank Shawn L. Berman, Professor of Organizational Studies, at University of New Mexico, for helpful discussions.

\section{Conflicts of Interest}

The author declares no conflicts of interest regarding the publication of this paper. 


\section{References}

[1] Kim, Y., Park, M.S. and Wier, B. (2012) Is Earnings Quality Associated with Corporate Social Responsibility. Accounting Review, 87, 761-796. https://doi.org/10.2308/accr-10209

[2] Cyert, R.M. and March, J.G. (1992) A Behavioral Theory of the Firm. Second Edition, Blackwell Publishers, Cambridge.

[3] Cyert, R.M. and March, J.G. (1963) A Behavioral Theory of the Firm. Prentice Hall, Englewood Cliffs.

[4] Penrose, E.T. (1959) The Theory of the Growth of the Firm. John Wiley \& Sons, New York.

[5] March, J.G. and Simon, H.A. (1958) Organizations. John Wiley \& Sons, New York.

[6] Shleifer, A. and Vishny, R.W. (1997) A Survey of Corporate Governance. Journal of Finance, 52, 737-783. https://doi.org/10.1111/j.1540-6261.1997.tb04820.x

[7] March, J.G. (1981) Footnotes to Organizational Change. Administrative Science Quarterly, 26, 563-577. https://doi.org/10.2307/2392340

[8] Hannan, M.T. and Freeman, J. (1984) Structural Inertia and Organizational Change. American Sociological Review, 49, 149-164. https://doi.org/10.2307/2095567

[9] Hannan, M.T. and Freeman, J. (1977) The Population Ecology of Organization. American Journal of Sociology, 82, 929-964. https://doi.org/10.1086/226424

[10] Stinchcombe, A.S. (1965) Social Structure and Organizations. In: March, J.G. Ed., Handbook of Organizations, Rand McNally, Chicago, 153-193.

[11] Brüderl, J. and Schüssler, R. (1990) Organizational Mortality: The Liabilities of Newness and Adolescence. Administrative Science Quarterly, 35, 530-547. https://doi.org/10.2307/2393316

[12] Hannan, M.T. (1998) Rethinking Age-Dependence in Organizational Mortality: Logical Formalizations. American Journal of Sociology, 104, 126-164. https://doi.org/10.1086/210004

[13] Merton, R.K. (1940) Bureaucratic Structure and Personality. Social Forces, 18, 560-568. https://doi.org/10.2307/2570634

[14] Mannheim, K. (1935) Mensch und Gesellschaft im Zeitalter des Umbaus. A. W. Sijthoff, Leiden.

[15] Mannheim, K. (2940) Man and Society in Age of Reconstruction: Studies in Modern Social Structure. Routledge, London.

[16] Penrose, P. and Pitelis, C. (1999) Edith Elura Tilton Penrose: Life, Contributions and Influence. Contributions to Political Economy, 18, 3-22. https://doi.org/10.1093/cpe/18.1.3

[17] Pitelis, C. (2002) The Growth of the Firm: The Legacy of Edith Penrose. Oxford University Press, Oxford.

[18] Newbert, S.L. (2007) Empirical Research on the Resource-Based View of the Firm: An Assessment and Suggestions for Future Research. Strategic Management Journal, 28, 121-146. https://doi.org/10.1002/smj.573

[19] Acedo, F.J., Barroso, C. and Galan, J.L. (2006) The Resource-Based Theory: Dissemination and Main Trends. Strategic Management Journal, 27, 621-636. https://doi.org/10.1002/smj.532

[20] Rugman, A.M. and Verbeke, A. (2002) Edith Penrose's Contribution to the Re- 
source-Based View of Strategic Management. Strategic Management Journal, 23, 769-780. https://doi.org/10.1002/smj.240

[21] Wernerfelt, B. (1995) The Resource-Based View of the Firm: Ten Years After. Strategic Management Journal, 16, 171-174. https://doi.org/10.1002/smj.4250160303

[22] Wernerfelt, B. (1984) A Resource-Based View of the Firm. Strategic Management Journal, 5, 171-180. https://doi.org/10.1002/smj.4250050207

[23] Barney, J.B. (2001) Is the Resource-Based "View" a Useful Perspective for Strategic Management Research? Yes. Academy of Management Review, 26, 41-56. https://doi.org/10.5465/amr.2001.4011938

[24] Barney, J.B. (2001) Resource-Based Theories of Competitive Advantage: A Ten-Year Retrospective on the Resource-Based View. Journal of Management, 27, 643-650. https://doi.org/10.1016/S0149-2063(01)00115-5

[25] Barney, J. (1991) Firm Resources and Sustained Competitive Advantage. Journal of Management, 17, 99-120. https://doi.org/10.1177/014920639101700108

[26] Barney, J.B. (1986) Strategic Factor Markets: Expectations, Luck, and Business Strategy. Management Science, 32, 1231-1241.

https://doi.org/10.1287/mnsc.32.10.1231

[27] Barney, J.B. (1986) Organizational Culture: Can It Be a Source of Sustained Competitive Advantage? Academy of Management Review, 11, 656-665. https://doi.org/10.5465/amr.1986.4306261

[28] Barney, J., Wright, M. and Ketchen, D.J. (2001) The Resource-Based View of the Firm: Ten Years after 1991. Journal of Management, 27, 625-641. https://doi.org/10.1177/014920630102700601

[29] Penrose, E.T. (1995) The Theory of the Growth of the Firm. Third Edition, Oxford University Press, Oxford.

[30] Pitelis, C.N. (2009) The Sustainable Competitive Advantage and Catching-Up of Nations: FDI, Clusters and the Liability (Asset) of Smallness. Management International Review, 49, 95-120. https://doi.org/10.1007/s11575-008-0127-4

[31] Pitelis, C.N. (2007) A behavioral Resource-Based View of the Firm: The Synergy of Cyert and March (1963) and Penrose (1959). Organization Science, 18, 478-490. https://doi.org/10.1287/orsc.1060.0244

[32] Pitelis, C. (2007) Edith Penrose and a Learning-Based Perspective on the MNE and OLI. Management International Review, 47, 207-219. https://doi.org/10.1007/s11575-007-0012-6

[33] Pitelis, C. (2005) Edith Penrose, Organisational Economics and Business Strategy: An Assessment and Extension. Managerial and Decision Economics, 26, 67-82. https://doi.org/10.1002/mde.1215

[34] Pitelis, C.N. (2004) Edith Penrose and the Resource-Based View of International Business Strategy. International Business Review, 13, 523-532. https://doi.org/10.1016/j.ibusrev.2004.04.002

[35] Pitelis, C. (2000) A Theory of the (Growth of the) Transnational Firm: A Penrosean Perspective. Contributions to Political Economy, 19, 71-89. https://doi.org/10.1093/cpe/19.1.71

[36] Pitelis, C.N. and Pseiridis, A.N. (1999) Transaction Costs versus Resource Value? Journal of Economic Studies, 26, 221-240. https://doi.org/10.1108/01443589910284408

[37] Turvani, M. (2002) Mismatching by Design: Explaining the Dynamics of Innovative Capabilities of the Firm with a Penrosean Mark. In: Pitelis, C., Ed., The Growth of 
the Firm: The Legacy of Edith Penrose, Oxford University Press, Oxford, 195-213.

[38] Evans, D.S. (1987) The Relationship between Firm Growth, Size, and Age: Estimates for 100 Manufacturing Industries. Journal of Industrial Economics, 35, 567-581. https://doi.org/10.2307/2098588

[39] Evans, D.S. (1987) Tests of Alternative Theories of Firm Growth. Journal of Political Economy, 95, 657-674. https://doi.org/10.1086/261480

[40] Jovanovic, B. (1982) Selection and Evolution of Industry. Econometrica, 50, 649-670. https://doi.org/10.2307/1912606

[41] Leonard-Barton, D. (1992) Core Capabilities and Core Rigidities: A Paradox in Managing New Product Development. Strategic Management Journal, 13, 111-125. https://doi.org/10.1002/smj.4250131009

[42] Christensen, C.M. and Bower, J.L. (1996) Customer Power, Strategic Investment, and the Failure of Leading Firms. Strategic Management Journal, 17, 197-218. https://doi.org/10.1002/(SICI)1097-0266(199603)17:3<197::AID-SMJ804>3.0.CO;2$\underline{\mathrm{U}}$

[43] Cameron, K.S. and Whetten, D.A. (1981) Perceptions of Organizational Effectiveness over Organizational Life Cycles. Administrative Science Quarterly, 26, 525-544. https://doi.org/10.2307/2392338

[44] Henderson, A.D. (1997) Firm Strategy and Age Dependence: A Contingent View of the Liabilities of Newness, Adolescence, and Obsolescence. Academy of Management Best Papers Proceedings, 1997, 263-266. https://doi.org/10.5465/ambpp.1997.4982221

[45] Dixit, A.K. and Stiglitz, J.E. (1977) Monopolistic Competition and Optimum Product Diversity. American Economic Review, 67, 297-308.

[46] Commons, J.R. (1931) Institutional Economics. American Economic Review, 21, 648-657.

[47] Coase, R.H. (1937) The Nature of the Firm. Economica, 4, 386-405. https://doi.org/10.1111/j.1468-0335.1937.tb00002.x

[48] Penrose, E.T. (1996) Growth of the Firm and Networking. In: International Encyclopaedia of Business and Management, Routlege, London, 1716-1724.

[49] Williamson, O.E. (1979) Transaction-Cost Economics: The Governance of Contractual Relations. Journal of Law and Economics, 22, 233-261.

https://doi.org/10.1086/466942

[50] Williamson, O.E. (1981) The Economics of Organization. The Transaction Cost Approach, 87, 548-577. https://doi.org/10.1086/227496

[51] Williamson, O.E. (1988) The Logic of Economic Organization. Journal of Law, Economics, \& Organization, 4, 65-93.

[52] Williamson, O.E. (1988) Corporate Finance and Corporate Governance. Journal of Finance, 43, 567-591. https://doi.org/10.1111/j.1540-6261.1988.tb04592.x

[53] Berle, A.A. and Means, G.C. (1932) The Modern Corporation and Private Property. Macmillan, New York.

[54] Burnham, J. (1941) The Managerial Revolution: or, What Is Happening in the World Now. Putnam, London.

[55] Cooper, W.W. (1951) A Proposal for Extending the Theory of the Firm. Quarterly Journal of Economics, 65, 87-109. https://doi.org/10.2307/1879501

[56] Alchian, A.A. and Demsetz, H. (1972) Production, Information Costs, and Economic Organization. American Economic Review, 62, 777-795. 
[57] Mitnick, B.M. (1973) Fiduciary Rationality and Public Policy: The Theory of Agency and Some Consequences. Working Paper, University of Pittsburgh, Pittsburgh. https://doi.org/10.2139/ssrn.1020859

[58] Ross, S.A. (1973) The Economic Theory of Agency: The Principal's Problem. American Economic Review, 63, 134-139.

[59] Jensen, M.C. and Meckling, W.H. (1976) Theory of the Firm: Managerial Behavior, Agency Costs and Ownership Structure. Journal of Financial Economics, 3, 305-360. https://doi.org/10.1016/0304-405X(76)90026-X

[60] Fama, E.F. (1980) Agency Problems and the Theory of the Firm. Journal of Political Economy, 88, 288-307. https://doi.org/10.1086/260866

[61] Arrow, K.J. (1985) The Economics of Agency. In: Pratt, J.W. and Zeckhauser, R.J., Eds., Principals and Agents: The Structure of Business, Harvard Business School Press, Boston, 37-51.

[62] Levinthal, D. (1988) A Survey of Agency Models of Organizations. Journal of Economic Behavior \& Organization, 9, 153-185.

https://doi.org/10.1016/0167-2681(88)90071-6

[63] Gillan, S.L., Hartzell, J.C. and Starks, L.T. (2011) Tradeoffs in Corporate Governance: Evidence from Board Structures and Charter Provisions. Quarterly Journal of Finance, 1, 667-706. https://doi.org/10.1142/S2010139211000183

[64] Berry, T.K., Fields, L.P. and Wilkins, M.S. (2006) The Interaction among Multiple Governance Mechanisms in Young Newly Public Firms. Journal of Corporate Finance, 12, 449-466. https://doi.org/10.1016/j.jcorpfin.2005.08.003

[65] Boone, A.L., Field, L.C., Karpoff, J.M. and Raheja, C.G. (2007) The Determinants of Corporate Board Size and Composition: An Empirical Analysis. Journal of Financial Economics, 85, 66-101. https://doi.org/10.1016/j.jfineco.2006.05.004

[66] Loderer, C. and Waelchli, U. (2011) Firm Age and Governance. Working Paper, University of Bern, Bern. https://doi.org/10.2139/ssrn.1938635

[67] Vintilă, G. and Gherghina, Ş.C. (2012) An Empirical Investigation of the Relationship between Corporate Governance Mechanisms, CEO Characteristics and Listed Companies' Performance. International Business Research, 5, 175-191. https://doi.org/10.5539/ibr.v5n10p175

[68] Landier, A., Sauvagnat, J., Sraer, D. and Thesmar, D. (2013) Bottom-Up Corporate Governance. Review of Finance, 17, 161-201. https://doi.org/10.1093/rof/rfs020

[69] Mueller, D.C. (1972) A Life Cycle Theory of the Firm. Journal of Industrial Economics, 42, 199-219. https://doi.org/10.2307/2098055

[70] Shumway, T. (2001) Forecasting Bankruptcy More Accurately: A Simple Hazard Model. Journal of Business, 74, 101-124. https://doi.org/10.1086/209665

[71] DeAngelo, H., DeAngelo, L. and Stulz, R.M. (2006) Dividend Policy and the Earned/Contributed Capital Mix: A Test of the Life-Cycle Theory? Journal of Financial Economics, 81, 227-254. https://doi.org/10.1016/j.jfineco.2005.07.005

[72] Grullon, G., Michaely, R. and Swaminathan, B. (2002) Are Dividend Changes a Sign of Firm Maturity? Journal of Business, 75, 387-424. https://doi.org/10.1086/339889

[73] Fama, E.F. and French, K.R. (2001) Disappearing Dividends: Changing Firm Characteristics or Lower Propensity to Pay? Journal of Financial Economics, 60, 3-43. https://doi.org/10.1016/S0304-405X(01)00038-1

[74] Loderer, C., Stulz, R. and Waelchi, U. (2013) Limited Managerial Attention and Corporate Aging, Working Paper, NBER, Cambridge.

https://doi.org/10.3386/w19428 
[75] Ouimet, P. and Zarutskie, R. (2014) Who Works for Startups? The Relation between Firm Age, Employee Age, and Growth. Journal of Financial Economics, 112, 386-407. https://doi.org/10.1016/j.jfineco.2014.03.003

[76] Arbuthnott, J. (1710) An Argument for Divine Providence, Taken from the Constant Regularity Observ'd in the Births of Both Sexes. Philosophical Transactions, 27, 186-190. https://doi.org/10.1098/rstl.1710.0011

[77] Fisher, R.A. (1925) Statistical Methods for Research Workers. Oliver and Boyd, London.

[78] Fisher, R.A. (1922) On the Mathematical Foundations of Theoretical Statistics. Philosophical Transactions of the Royal Society of London, Series A, Containing Papers of a Mathematical or Physical Character, 222, 309-368.

https://doi.org/10.1098/rsta.1922.0009

[79] Neyman, J. and Pearson, E.S. (1933) On the Problem of the Most Efficient Tests of Statistical Hypotheses. Philosophical Transactions of the Royal Society of London, Series A, Containing Papers of a Mathematical or Physical Character, 231, 289-337. https://doi.org/10.1098/rsta.1933.0009

[80] Boring, E.G. (1919) Mathematical vs. Scientific Significance. Psychological Bulletin, 16, 335-338. https://doi.org/10.1037/h0074554

[81] Berkson, J. (1938) Some Difficulties of Interpretation Encountered in the Application of the Chi-Square Test. Journal of the American Statistical Association, 33, 526-536. https://doi.org/10.1080/01621459.1938.10502329

[82] Rozeboom, W.W. (1960) The Fallacy of the Null Hypothesis Significance Test. Psychological Bulletin, 57, 416-428. https://doi.org/10.1037/h0042040

[83] Carver, R.P. (1978) The Case against Statistical Significance Testing. Harvard Educational Review, 48, 378-399. https://doi.org/10.17763/haer.48.3.t490261645281841

[84] Cohen, J. (1994) The Earth is Round ( $\mathrm{p}<.05)$. American Psychologist, 49, 997-1003. https://doi.org/10.1037/0003-066X.49.12.997

[85] Cohen, J. (1990) The Things I Have Learned (So Far). American Psychologist, 45, 1304-1312. https://doi.org/10.1037/0003-066X.45.12.1304

[86] Schmidt, F.L. (1996) Statistical Significance Testing and Cumulative Knowledge in Psychology: Implications for the Training of Researchers. Psychological Methods, $\mathbf{1}$, 115-129. https://doi.org/10.1037/1082-989X.1.2.115

[87] Anderson, D.R., Burnham, K.P. and Thompson, W.L. (2000) Null Hypothesis Testing: Problems, Prevalence, and an Alternative. Journal of Wildlife Management, 64, 912-923. https://doi.org/10.2307/3803199

[88] Thompson, B. (1993) The Use of Statistical Significance Tests in Research: Bootstrap and Other Alternatives. Journal of Experimental Education, 61, 361-377. https://doi.org/10.1080/00220973.1993.10806596

[89] Thompson, B. (1996) AERA Editorial Policies Regarding Statistical Significance Testing: Three Suggested Reforms. Educational Researcher, 25, 26-30. https://doi.org/10.2307/1176337

[90] Thompson, B. (1997) Rejoinder: Editorial Policies Regarding Statistical Significance Testing: Further Comments. Educational Researcher, 26, 29-32. https://doi.org/10.3102/0013189X026005029

[91] Thompson, B. (2002) "Statistical", "Practical”, and "Clinical": How Many Kinds of Significance Do Counselors Need to Consider? Journal of Counseling and Development, 80, 64-71. https://doi.org/10.1002/j.1556-6678.2002.tb00167.x

[92] Thompson, B. (2002) What Future Quantitative Social Science Research Could 
Look Like: Confidence Intervals for Effect Sizes. Educational Researcher, 31, 24-31. https://doi.org/10.3102/0013189X031003025

[93] Thompson, B. (2004) The "Significance" Crisis in Psychology and Education. Journal of Socio-Economics, 33, 607-613. https://doi.org/10.1016/j.socec.2004.09.034

[94] Lendrem, B.A.D., Lendrem, D.W., Gray, A. and Isaacs, J.D. (2014) The Darwin Awards: Sex Differences in Idiotic Behaviour. BMJ, 349, g7094. https://doi.org/10.1136/bmj.g7094

[95] Hubbard, R. (1995) The Earth Is Highly Significantly Round ( $<$.0001). American Psychologist, 50, 1098. https://doi.org/10.1037/0003-066X.50.12.1098.a

[96] Hubbard, R. and Ryan, P.A. (2000) The Historical Growth of Statistical Significance Testing in Psychology and Its Future Prospects. Educational and Psychological Measurement, 60, 661-681. https://doi.org/10.1177/00131640021970808

[97] Huberty, C.J. (1999) On Some History Regarding Statistical Testing. In: Thompson, B., Ed., Advances in Social Science Methodology, Vol. 5, Jai Press, Stamford, 1-23.

[98] Huberty, C.J. (1987) On Statistical Testing. Educational Researcher, 16, 4-9. https://doi.org/10.3102/0013189X016008004

[99] Kline, R.B. (2004) Beyond Significance Testing: Reforming Data Analysis Methods in Behavioral Research. American Psychological Association, Washington DC. https://doi.org/10.1037/10693-000

[100] Tyler, R.W. (1931) What Is Statistical Significance? Educational Research Bulletin, 10, $115-118+142$.

[101] Arrow, K.J. (1959) Decision Theory and the Choice of a Level of Significance for the t-Test. In: Olkin, I., et al., Eds., Contributions to Probability and Statistics. Essays in Honor of Harold Hotelling, Stanford University Press, Stanford, 70-78.

[102] Cumming, G. (2012) Understanding the New Statistics: Effect Sizes, Confidence Intervals, and Meta-Analysis. Routledge, New York. https://doi.org/10.4324/9780203807002

[103] American Psychological Association (1994) Publication Manual of the American Psychological Association. Fourth Edition, APA, Washington DC.

[104] American Psychological Association (2001) Publication Manual of the American Psychological Association. Fifth Edition, APA, Washington DC.

[105] American Psychological Association (2010) Publication Manual of the American Psychological Association. Sixth Edition, APA, Washington DC.

[106] Mbengué, A. (2010) Should We Burn the Statistical Significance Tests? Management, 13, 99-127. https://doi.org/10.3917/mana.132.0100

[107] Huberty, C.J. (2002) A History of Effect Size Indices. Educational and Psychological Measurement, 62, 227-240. https://doi.org/10.1177/0013164402062002002

[108] Kirk, R.E. (1996) Practical Significance: A Concept Whose Time Has Come. Educational and Psychological Measurement, 56, 746-759. https://doi.org/10.1177/0013164496056005002

[109] Ziliak, S.T. and McCloskey, D.N. (2004) Size Matters: The Standard Error of Regressions in the American Economic Review. Journal of Socio-Economics, 33, 527-546. https://doi.org/10.1016/j.socec.2004.09.024

[110] McCloskey, D.N. and Ziliak, S.T. (1996) The Standard Error of Regressions. Journal of Economic Literature, 34, 97-114.

[111] Zellner, A. (1984) Posterior Odds Ratios for Regression Hypotheses: General Considerations and Some Specific Results. In: Zellner, A., Ed., Basic Issues in Econome- 
trics, University of Chicago Press, Chicago, 275-305.

[112] Lecoutre, B. (1999) Beyond the Significance Test Controversy: Prime Time for Bayes? 52nd Session, International Statistical Institute, Voorburg.

http://epeire.univ-rouen.fr/labos/eris/pac.html

[113] Lecoutre, B., Lecoutre, M.-P. and Poitevineau, J. (2001) Uses, Abuses and Misuses of Significance Tests in the Scientific Community: Won't the Bayesian Choice Be Unavoidable? International Statistical Review, 69, 399-417. https://doi.org/10.1111/j.1751-5823.2001.tb00466.x

[114] Eliott, G. and Granger, C.W.J. (2004) Evaluating Significance: Comments on "Size Matters". Journal of Socio-Economics, 33, 547-550. https://doi.org/10.1016/j.socec.2004.09.025

[115] Horowitz, J.L. (2004) Comments on "Size Matters". Journal of Socio-Economics, 33, 551-554. https://doi.org/10.1016/j.socec.2004.09.026

[116] Leamer, E.E. (2004) Are the Roads Red? Comments on "Size Matters". Journal of Socio-Economics, 33, 555-557. https://doi.org/10.1016/j.socec.2004.09.027

[117] O’Brien, A.P. (2004) Why Is the Standard Error of Regression So Low Using Historical Data? Comments on "Size Matters". Journal of Socio-Economics, 33, 565-570. https://doi.org/10.1016/S1053-5357(04)00088-5

[118] Wooldridge, J.M. (2004) Statistical Significance Is Okay, Too: Comment on "Size Matters". Journal of Socio-Economics, 33, 577-579.

https://doi.org/10.1016/j.socec.2004.09.031

[119] Gigerenzer, G. (2004) Mindless Statistics. Journal of Socio-Economics, 33, 587-606. https://doi.org/10.1016/j.socec.2004.09.033

[120] Altman, M. (2004) Introduction: Statistical Significance. Journal of Socio-Economics, 33, 523-525. https://doi.org/10.1016/j.socec.2004.09.023

[121] Sawyer, A.G. and Peter, J.P. (1983) The Significance of Statistical Significance Tests in Marketing Research. Journal of Marketing Research, 20, 122-133. https://doi.org/10.1177/002224378302000203

[122] Armstrong, J.S. (2007) Significance Tests Harm Progress in Forecasting. International Journal of Forecasting, 23, 321-327. https://doi.org/10.1016/j.ijforecast.2007.03.004

[123] Armstrong, J.S. (2007) Statistical Significance Tests Are Unnecessary Even When Properly Done and Properly Interpreted: Reply to Commentaries. International Journal of Forecasting, 23, 335-336. https://doi.org/10.1016/j.ijforecast.2007.01.010

[124] Huselid, M.A. (1995) The Impact of Human Resource Management Practices on Turnover, Productivity, and Corporate Financial Performance. Academy of Management Journal, 38, 635-672. https://doi.org/10.2307/256741

[125] MacDuffie, J. (1995) Human Resource Bundles and Manufacturing Performance: Organizational Logic and Flexible Production Systems in the World Auto Industry. Industrial and Labor Relations Review, 48, 197-221. https://doi.org/10.1177/001979399504800201

[126] Huselid, M.A. (1996) Methodological Issues in Cross-Sectional and Panel Estimates of the Human Resource-Firm Performance Link. Industrial Relations, 35, 400-422. https://doi.org/10.1111/j.1468-232X.1996.tb00413.x

[127] Gerhart, B. (1999) Human Resource Management and Firm Performance: Measurement Issues and Their Effect on Causal and Policy Inferences. In: Wright, P.M., Dyer, L.D., Bourdreau, J.W. and Milkovich, G.T., Eds., Research in Personnel and Human Resources Management, Supplement 4, Jai Press, Stamford, 31-51. 
[128] Gerhart, B., Wright, P.M., McMahan, G.C. and Snell, S.A. (2000) Measurement Error in Research on Human Resources and Firm Performance: How Much Error Is There and How Does It Influence Effect Size Estimates? Personnel Psychology, 53, 803-834. https://doi.org/10.1111/j.1744-6570.2000.tb02418.x

[129] Gerhart, B., Wright, P.M. and McMahan, G.C. (2000) Measurement Error in Research on Human Resources and Firm Performance Relationship: Further Evidence and Analysis. Personnel Psychology, 53, 855-872.

https://doi.org/10.1111/j.1744-6570.2000.tb02420.x

[130] Huselid, M.A. and Becker, B.E. (2000) Comment on Measurement Error in Research on Human Resources and Firm Performance: How Much Error Is There and How Does It Influence Effect Size Estimates? Personnel Psychology, 53, 835-854. https://doi.org/10.1111/j.1744-6570.2000.tb02419.x

[131] Wright, P.M., Gardner, T.M., Moynihan, L.M., Park, H.J., Gerhart, B. and Delery, J.E. (2001) Measurement Error in Research on Human Resources and Firm Performance: Additional Data and Suggestions for Future Research. Personnel Psychology, 54, 875-902. https://doi.org/10.1111/j.1744-6570.2001.tb00235.x

[132] Combs, J., Liu, Y., Hall, A. and Ketchen, D. (2006) How Much Do High-Performance Work Practices Matter? A Meta-Analysis of Their Effects on Organizational Performance. Personnel Psychology, 59, 501-528. https://doi.org/10.1111/j.1744-6570.2006.00045.x

[133] Becker, B.E. and Huselid, M.A. (2006) Strategic Human Resources Management: Where Do We Go From Here? Journal of Management, 32, 898-925. https://doi.org/10.1177/0149206306293668

[134] Ellis, P.D. (2010) Effect Sizes and the Interpretation of Research Results in International Business. Journal of International Business Studies, 41, 1581-1588. https://doi.org/10.1057/jibs.2010.39

[135] Ellis, P.D. (2009) Thresholds for Interpreting Effect Sizes. http://www.polyu.edu.hk/mm/effectsizefaqs/thresholds_for_interpreting_effect_size s2.html

[136] Ellis, P.D. (2010) The Essential Guide to Effect Sizes: An Introduction to Statistical Power, Meta-Analysis, and the Interpretation of Research Results. Cambridge University Press, Cambridge.

[137] Simon, H.A. (1992) What Is an "Explanation" of Behavior? Psychological Science, 3, 150-161. https://doi.org/10.1111/j.1467-9280.1992.tb00017.x

[138] Magee, D. (2009) Jeff Immelt and the New GE Way: Innovation, Transformation, and Winning in the 21st Century. McGraw-Hill, New York.

[139] Owles, E. (2017) G.E.'s History of Innovation. New York Times, June 12.

[140] Bennett, D. (2018) How GE Went From American Icon to Astonishing Mess. Bloomberg Businessweek, February 1. https://www.bloomberg.com/news/features/2018-02-01/how-ge-went-from-america n-icon-to-astonishing-mess

[141] Colvin, G. (2018) What the Hell Happened at GE? Fortune, May 24. http://fortune.com/longform/ge-decline-what-the-hell-happened

[142] Gryta, T. and Mann, T. (2018) GE Powered the American Century-Then It Burned Out. Wall Street Journal, December 14.

https://www.wsj.com/articles/ge-powered-the-american-centurythen-it-burned-out $-11544796010$ 